OPEN ACCESS

Edited by:

José Manuel Mirás-Avalos, Universidade de Santiago de

Compostela, Spain

Reviewed by: Fei WANG

Institute of Soil and Water Conservation (CAS), China

Aitor García Tomillo,

University of A Coruña, Spain

*Correspondence:

Berit Arheimer

Berit.Arheimer@smhi.se

Specialty section:

This article was submitted to Agroecology and Ecosystem Services,

a section of the journal

Frontiers in Environmental Science

Received: 03 March 2018

Accepted: 23 August 2018

Published: 18 September 2018

Citation:

Arheimer B, Hjerdt N and Lindström G (2018) Artificially Induced Floods to Manage Forest Habitats Under Climate Change.

Front. Environ. Sci. 6:102. doi: 10.3389/fenvs.2018.00102

\section{Artificially Induced Floods to Manage Forest Habitats Under Climate Change}

\author{
Berit Arheimer*, Niclas Hjerdt and Göran Lindström \\ Swedish Meteorological and Hydrological Institute, Norrköping, Sweden
}

Global change is affecting agroforestry and its inherent ecosystems in Sweden. Here we examine the benefits of ecologically adjusted dam regulations to conserve biodiversity under climate change in floodplain habitats, including meadows and riparian mixed forests. The natural flood regime in snow-dominated regions has changed significantly during the last decades, in line with the projections for climate change. The ecosystems of temporary flooded forests show high biodiversity but are dependent on river high flows with long duration. These events are rare in the new climate scenario, but on the other hand, snow-fed rivers are also affected by hydropower dams and regulations. In this study we explored the potential of using reservoir regulation to artificially induce flood events; water management would then be a method to conserve biodiversity in forest habitats and adapt management to climate change. We made detailed calculations in lower Dalälven River, central Sweden, using observed time-series of river flow and dynamic scenario modeling for highly valuable Natura 2000 habitats. Here we show that long-term flooding is less frequent since extensive hydropower was introduced during the 1920s, and moreover, since the 1990's the spring floods are low due to low snow storage and short winter seasons. Sustainable management of $50 \%$ of the riparian forest requires flooding by 25 continuous days of $800 \mathrm{~m}^{3} \mathrm{~s}^{-1}$. We found that artificial floods using new ecological regulation regime of upstream hydropower reservoirs would help, but not be enough, to achieve this goal. The new regulation routines would correspond to a loss of 50-200 GWh in hydropower production for each artificial flood. Sustainable ecosystems in the study site do not request flooding every year, but some every fifth year. For practical implementation, the County Board is currently driving the process locally and we discuss the relevant social features, such as legal and funding aspects, of this adaptive management of water and forests. A smaller part of the forest could probably be rescued and costs could potentially be lowered by using only the most snow rich years and seasonal forecasting of river flow for optimal timing of water release from dams to induce flooding.

Keywords: environmental flow, river regulation, climate change, climate adaptation, biodiversity, water management, floodplains 


\section{INTRODUCTION}

Currently, productive forests account for 57\% of the Swedish land cover and they have been constantly expanding throughout the 20th century (KSLA, 2015; Nilsson et al., 2016). During the last century, forests in Sweden have seen important changes in forest structure and composition (Antonson and Jansson, 2011). Agroforestry is responsible for most changes in the diversity of coniferous and deciduous species (Laudon et al., 2011; Elmhagen et al., 2015), yet, climate change and water management may also have a severe impact on biodiversity in these forests. The highest biodiversity in Sweden is found in ecotopes of temporarily flooded riparian mixed forests, which have been recognized as highly valuable Natura 2000 habitats (Hedström-Ringvall et al., 2017a). The high biodiversity is dependent on river high flows with long duration, but such occasions have become rare during the last decades. As a consequence, there is a great concern about the possible disappearance of these valuable ecosystems.

The flood regime in snow-dominated regions has changed significantly during the last decades, which is in line with the projections for climate change impact but also an effect of extensive flow regulations (Arheimer et al., 2017). During the cold part of the year in Sweden, water is stored as snow and ice, which fully or partly melt during the spring. The natural flow regime is therefore characterized by low flow during the winter followed by a high spring peak flood event. The ecosystems have evolved over time to benefit from these flow dynamics with high biodiversity in the floodplains as an outcome. Several studies of climate-change impacts on rivers show that the annual peak flood event may be less distinct and even disappear in some snow dominated areas (Molini et al., 2011; Godsey et al., 2013) as global warming will reduce the snow fall (Krasting et al., 2013) and/or snow storage period by the end of this century (Barnett et al., 2005). More precipitation falling as rain in snow-dominated regions and shorter freezing periods will thus give less difference in river flow between seasons and less flooding of floodplains during spring.

Arheimer et al. (2017) concluded that at the large scale and for floodplains in snow-dominated regions, hydropower production can have the same effect as climate change on the flow regime. During spring, the river water is stored in dams and reservoirs often to be released throughout the year whenever electricity is needed most. Thus, the high flow of the snow-melt season is damped and the river flow redistributed to other times of the year (e.g., Arheimer and Lindström, 2014). The negative effects on ecosystems that follow from river regulation are well known (e.g., Andersson et al., 2000; Bunn and Arthington, 2002; Leira and Cantonati, 2008) and in addition, ecosystems in regulated rivers are considered particularly vulnerable to climate change (e.g., Nilsson et al., 2005; Palmer et al., 2008). However, ecosystems affected by river regulations have also been suggested as more favorable for adaptation measures as flow regimes can be manipulated (e.g., Lytle and Poff, 2004; Rheinheimer and Viers, 2015). Artificially induced floods by changed regulation regimes at hydropower dams have been suggested as a possible climate adaptation measure to conserve biodiversity under climate change (Arheimer et al., 2017). Nevertheless, the potential of this management protocol still remains unknown and detailed site-specific investigations are needed in each case to justify any implementation, as large economic costs are involved from loss in energy production.

We here describe such a case study of central Sweden, where detailed calculations were made to: (i) analyse the reasons behind the reduced flooding that threatens a rare forest habitat, and (ii) explore the potential of using changed regulation strategy at upstream hydropower dams to induce river flooding for sustainable management. We found that reduction of snow storage was the main reason behind the loss of peak-flows during recent decades, and that changed regulation of hydropower dams could not save $50 \%$ of the habitats of the threatened temporarily flooded forest. We show that the regulations could help in climate adaptation, but there may be high costs for energy loss and meltwater must still be available in sufficient amounts from snow storage. Overall, the study highlights the importance of revising management protocols under non-stationary conditions due to global warming.

\section{MATERIALS AND METHODS}

\section{Study Site}

The floodplain forests of lower Dalälven River in central Sweden, receive water from a $29,000 \mathrm{~km}^{2}$ watershed starting in the mountains of Norway to the west, from which the river flows to the east and ends in the Baltic Sea (Figure 1). The regulation of Dalälven River started during the 1920's to produce electricity from hydropower reservoirs. Dams were constructed to store the water from snowmelt during spring, to be released for hydropower production throughout the year, especially during the long and dark winter when most electricity is needed in this region. Often natural lakes are regulated but in some cases new reservoirs were constructed. Altogether, the watershed encompasses about 125 dams at present, with a total regulated volume of $2,739 \mathrm{Mm}^{3}$ and a degree of regulation of 23.5\% (Arheimer et al., 2017). The total annual production is approximately $5 \mathrm{TWh}_{\text {year }}{ }^{-1}$. The most prominent dams are Gråda and Trängslet. Gråda is regulating the lake Siljan and was constructed during the 1920's with a head of 12 meters and volume of $660 \mathrm{Mm}^{3}$ (Hedström-Ringvall et al., 2017b). Trängslet is from 1950's with a head of 142 meters and a volume of $880 \mathrm{Mm}^{3}$. Both are owned by the company Fortum and the regulation schemes also affect many down-stream dams.

Several climate change impact studies have encompassed river flow in Dalälven River (e.g., Andréasson et al., 2004; Arheimer et al., 2017) and can also be found at the websites www. smhi.se or http://swicca.eu/. The climate change projections show an increase in mean annual air temperature by +3 to $+6^{\circ} \mathrm{C}$ at the end of the Twenty-First century, with a higher increase in winter $\left(+4\right.$ to $\left.+7^{\circ} \mathrm{C}\right)$ compared to summer temperatures $\left(+2\right.$ to $\left.+4^{\circ} \mathrm{C}\right)$. At the same time, annual precipitation is expected to increase by \pm 0 to $+30 \%$, with a higher increase in winter $(+20$ to $+40 \%)$ compared to summer precipitation $( \pm 0$ to $+20 \%)$. The growing season is expected to increase by 40 to 80 days at the end of the Twenty-First century. 


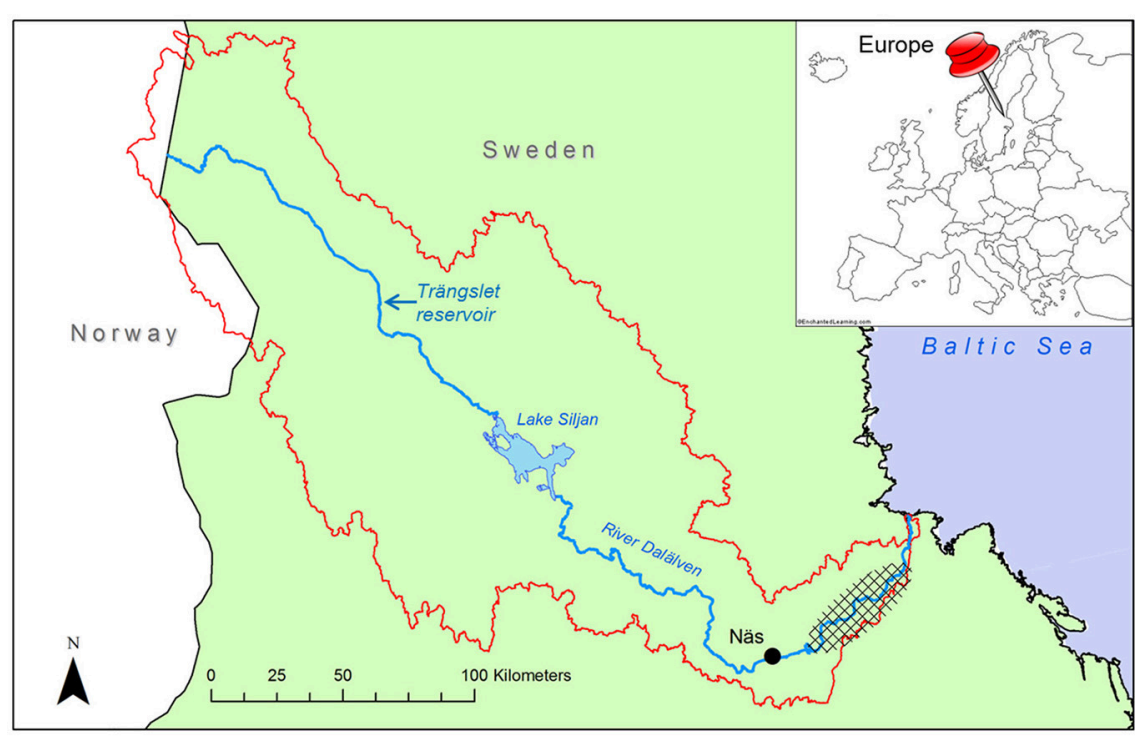

FIGURE 1 | Map showing the catchment borders (red line) of Dalälven River (blue line) in Northern Europe, and the location of the hydropower plant "Näs" (black dot) upstream the regularly flooded residua forest of high biodiversity (checkered).

\section{Environmental Flows for Forest Flooding}

The natural river regime with annual floods due to snowmelt during the spring has created a very unique zonation of ecosystems at various altitudes of the floodplains, depending on frequency and duration in flooding. The region is recognized as having the highest biodiversity in Sweden, with several valuable Natura 2000 habitats identified along the river floodplains. This is a unique service provided by the river from its original flow dynamics. The most vulnerable ecosystem is the regularly flooded riparian mixed forests, which requests flood duration of 25 continuous days to initiate the ecological processes and serve as habitat for the specific species living and growing there (Hedström-Ringvall et al., 2017b).

Differentiation of floodplain habitats was based on different elevation zones, using a topographic GIS analysis (Zinke, 2013). Each habitat needs specific flooding to sustain the diversity of species and different elevation zones will be flooded at different magnitudes of river flow. As most of floodplain habitats are located along wide, lake-like, sections of the river, the river flows required to flood these habitats were estimated from an analysis of habitat elevation zones and stage-discharge rating curves of the lake outlets (Figure 2). The topographical GIS analysis of the floodplains together with hydraulic modeling results show that river flow above $800 \mathrm{~m}^{3} \mathrm{~s}^{-1}$ will flood a significant part of the riparian mixed forest (the mean elevation minus one standard deviation, i.e., $56.4 \mathrm{~m}$, see Table 5, 6 by Zinke, 2013), while 1,250 $\mathrm{m}^{3} \mathrm{~s}^{-1}$ is needed for all forest representing these unique ecotopes to be flooded (Hedström-Ringvall et al., 2017a). In this study, the value $800 \mathrm{~m}^{3} \mathrm{~s}^{-1}$ was thus used as environmental flow for forest flooding to conserve the biodiversity in lower Dalälven River.

\section{Data and Methods}

Observed time-series of daily river flow were collected from the discharge stations at Långhag/Fäggeby (since

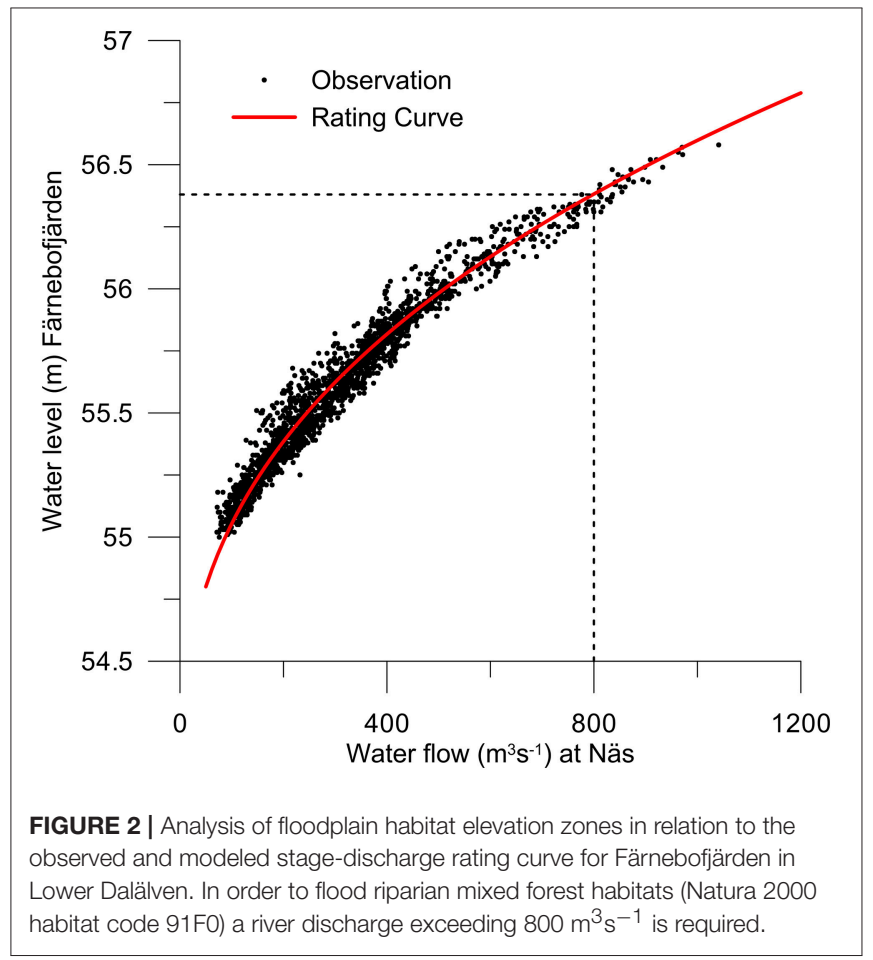

1851) and at Näs (since 1961). The stations are situated not far from each other in the main river channel close to the downstream floodplains. The observed data was used to analyse the long-term changes in river flow, which could be due to either climate variability/change or flow regulation in hydropower dams. Observed time-series from the hydropower stations Trängslet and Gråda (Lake Siljan) were used as a base-line when exploring effects from changed 
regulation routines to induce flooding for specific years (see below).

Dynamic modeling was performed using the numerical Hydrological Predictions for the Environment (HYPE) model (Lindström et al., 2010) as set up for Sweden in S-HYPE (Strömqvist et al., 2012). The model simulates flow generating processes from meteorological input data, by taking into account for instance snow melt, evapotranspiration, soil moisture, groundwater fluctuations, routing in lakes and streams. It also includes routines for simulating regulation in hydropower reservoirs (Arheimer and Lindström, 2014; Arheimer et al., 2017). In the national model setup, the Dalälven River basin is divided into 2,823 coupled watersheds along the river network.

The S-HYPE model was used to simulate the changes in snow storage between 1961 and 2015, to evaluate the impact from climate on observed changes in river regime. The S-HYPE model was also used to reconstruct the natural river flow, as it would have been without the influence of hydropower regulations, using the method described by Arheimer and Lindström (2014) and Arheimer et al. (2017). Return periods for daily environmental flows, were analyzed by dividing time series data into 30 -year periods and using the statistical method described by Bergstrand et al. (2014). Time series from two sources were used: Observed daily discharge from Långhag/Fäggeby for the period 1851-1920 (before the development of hydropower), and reconstructed natural daily discharge for Näs for the period 1961-2015 (after the development of hydropower), using the hydrological model S-HYPE.

To investigate future climate impact on river flow, the SHYPE model was used for climate change projections. It was then fed with time-series from the Coupled Model Intercomparison Project Phase 5 (CMIP5) from the Intergovernmental Panel on Climate Change (IPCC), using projections for two different assumptions on societal development and emission scenarios (Representative Concentration Pathways (RCPs) 4.5 and 8.5, respectively). Data was extracted from the Regional Climate model RCA (Samuelsson et al., 2011) version 4, using an ensemble of nine General Circulation Models (GCM): CanESM2, CNRM-CM5, GFDL-ESM2M, EC-EARTH, IPSL-CM5A-MR, MIROC5, MPI-EMS-LR, NorESM1-M, HadGEM2-ES. The RCA downscaled the GCM data from $1,000 \mathrm{~km}$ to $50 \mathrm{~km}$, as part of the Coordinated Regional Downscaling Experiment (CORDEX) initiative (http://www.cordex.org/). Thereafter statistical biascorrection was made using the distributed based scaling (DBS) method (Yang et al., 2010) to a Swedish $4 \mathrm{~km}$ meteorological grid based on observations (Johansson, 2002). To estimate future climate change impact on Dalälven River, the river flow at the end of the century (2068-2098) was compared with a reference period (1981-2010) for each ensemble member.

To explore the effects from inducing floods by changed regulation strategies, four alternative scenarios were constructed for the spring flood of recently wet years $(1999,2006,2010,2015)$ :

- Business as usual, using daily corrected observations from monitoring stations by the Swedish Meteorological and Hydrological Institute (SMHI).
- Scenario 1, reduced regulation from both Trängslet and Siljan hydropower dams.

- Scenario 2, reduced regulation only from Lake Siljan hydropower dam (Gråda).

- Natural flow calculated with the S-HYPE model as described by Arheimer and Lindström (2014) and Arheimer et al. (2017).

The calculations at both Trängslet and Siljan hydropower dams were made by the hydropower companies (Hedström-Ringvall et al., 2017a), using site-specific and detailed local information on regulation capacities, head, outlet conditions, and legal agreements on volumes, water levels, spill, and flow (HedströmRingvall et al., 2017b). They used their operational set-up of numerical models for production, based on the open access tool Hec ResSim from US Army Corps of the Engineers (http:// www.hec.usace.army.mil/software/hec-ressim/) as applied for the specific reservoirs. Additional lumped flow routing methods were used, as suggested by Chow et al. (1988). For scenario 1 and 2, the flows to downstream reservoirs were adjusted by applying the estimated change in flow from calculated regulations at Trängslet or Siljan to the observed flows at each site.

\section{RESULTS}

\section{Observed Changes in River Flow}

Long-term flooding is less frequent since extensive hydropower was introduced during the period 1920-1960 and the spring peak is less pronounced. Time-series of $>50$ years of observations both before and after building hydropower dams, show that the average in high water inflow causing flooding of the vulnerable forest habitat has dropped from 900 to $500 \mathrm{~m}^{3} \mathrm{~s}^{-1}$ due to regulation (Figure 3). The long-term average in flow is thus far from reaching the $800 \mathrm{~m}^{3} \mathrm{~s}^{-1}$ threshold for the modern time period, although specific years still exceed this threshold. Since the 1990's the annual spring-floods have been low due to low snow storage and short winter seasons. The spring peak also starts about 1 month earlier. These are results of a warming climate, which has already affected the flow regime in this region considerably. From the observed time-series, however, it is not possible to judge whether the observed change in flow regime is due to river regulations or climate change. However, our analysis of reconstructed natural flow using a hydrological model enables us to evaluate the potential effects of climate change separately. A comparison of measured flow before regulation (1852-1919) to reconstructed natural flow (1961-2015) clearly shows that the magnitude and duration of the spring-flood has decreased over the last decades.

\section{Observed Changes in Snow Storage}

Annual precipitation over the watershed upstream Näs hydropower station varies from 470 to $860 \mathrm{~mm}_{\text {year }}{ }^{-1}$, but there is a slight but significant increase in average annual precipitation over the last 55 years (Figure 4A). Our analysis shows that while annual precipitation increases over time, the fraction of precipitation falling as snow decreases and annual maximum snow storage decreases (Figures 4A,B). For unregulated areas, 
the reduced peak-flow during spring is thus a result from reduced snow-melt and not from reduced precipitation.

The annual maximum snow storage is a relatively good indicator of the spring flood volume, and therefore also flood duration (Figure 4C). Years with large maximum snow storage typically yield spring floods of long duration $\left(R^{2}=0.56\right.$, Figure 4C). On average, a maximum snow storage of about $160 \mathrm{~mm}$ is required to produce a spring flood that exceeds 25 days in duration, which is required to conserve $50 \%$ of the temporarily flooded riparian mixed forest. We found nine such years for the last 55 years, which could then be about enough for generating a designed flow peak of sufficient duration every fifth year.

\section{Changes in Return Periods of Environmental Flow}

There is a temporal variability in calculated return periods but more so for floods with long duration (Figure 5). Daily discharge above $800 \mathrm{~m}^{3} \mathrm{~s}^{-1}$ occurs on average every or every other year throughout the entire time period. Daily discharge above 800 $\mathrm{m}^{3} \mathrm{~s}^{-1}$ for at least 25 consecutive days in April-June occurred every 2-3 years in the period 1851-1920, but has become rarer after 1990. In the observed discharge data from Näs, springfloods with such high magnitude and duration have not occurred since the mid 1980s. However, in the reconstructed natural discharge for the last 30-year period investigated (1986-2015),

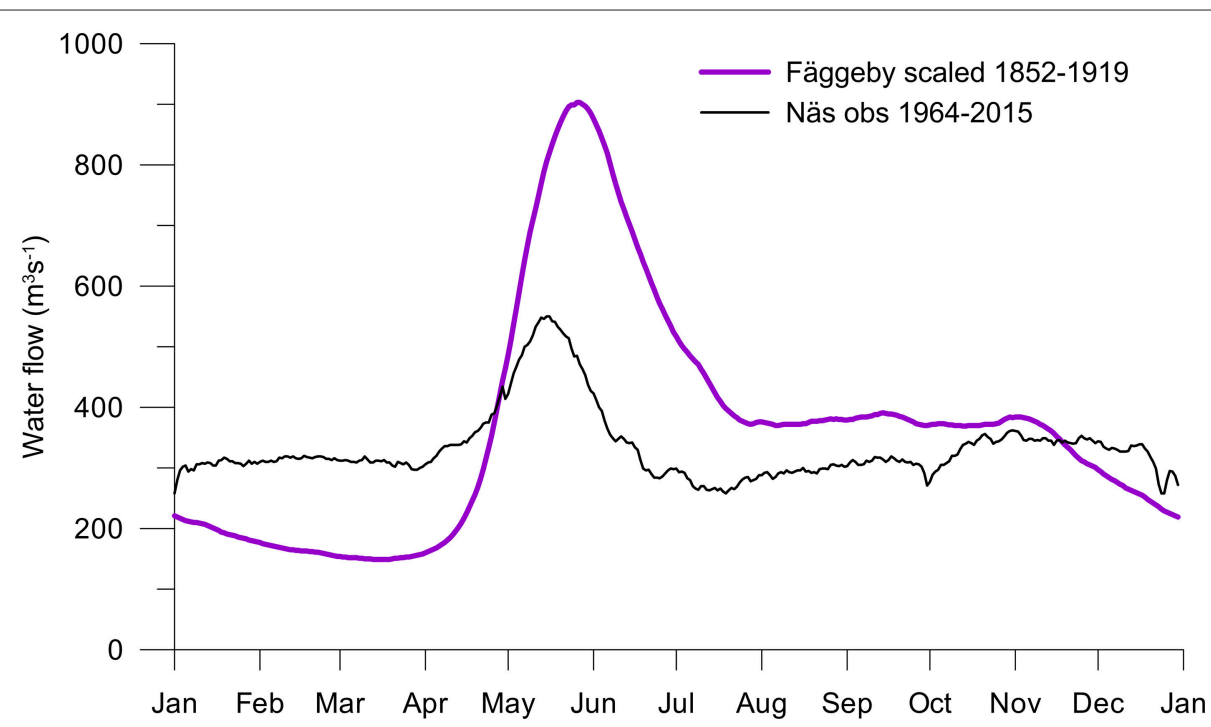

FIGURE 3 | Average water discharge at Näs, using scaled observation from the nearby river gauge at Fäggeby for the period before constructing hydropower dams (purple) and observations at Näs after regulations (black).
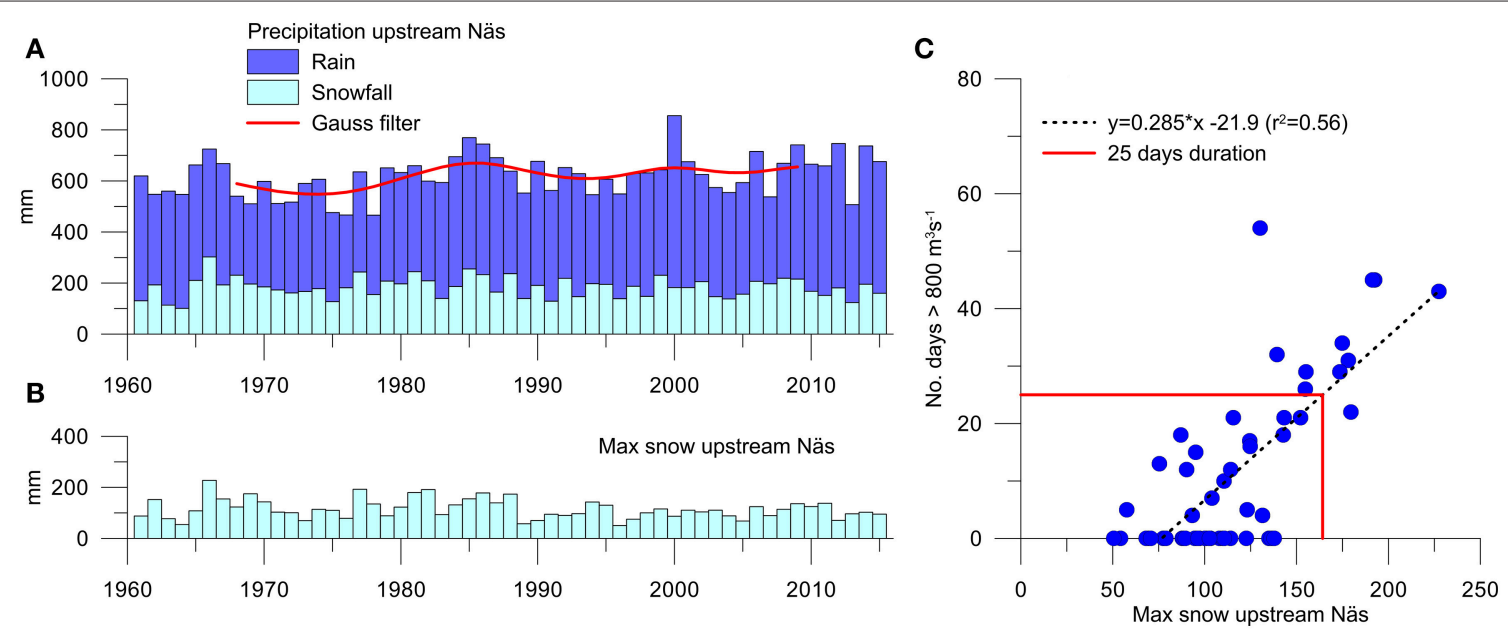

FIGURE 4 | Annual precipitation in Dalälven watershed upstream of Näs with fractions falling as rain and snow (A, upper left), annual maximum snow storage upstream of Näs (B, lower left), correlation between flood duration (continuous number of days of unregulated flow exceeding $800 \mathrm{~m}^{3} \mathrm{~s}^{-1} \mathrm{during}$ the period between April and June) and annual maximum snow storage upstream Näs (C, right). 
spring floods of long duration occurred every 6 years on average (Figure 5). This indicates again a change in climate and that future climate change may further reduce the potential for the targeted environmental flows.

\section{Projected Future Climate Change Impact}

Projections for Dalälven River suggest that climate change upstream the temporary flooded riparian mixed forest has less impact on the seasonal distribution of flow than current hydropower regulation (Figure 6). On average for the 30-year period studied, the natural spring flow has been reduced by $32 \%$ due to dam constructions (green vs. black line in Figure 6), while climate change is projected to reduce a natural spring peak by 13\% (blue vs. red line in Figure 6). The results from this analysis show that changes in hydropower regulation control the flow more than climate. This implies that changes in management protocols could be an efficient method to reconstruct the natural flows by opening the dam gates during the flow peak in spring. Although, it is not clear if the effect would be enough.

\section{Scenarios of Artificially Induced Floods}

Although the changed strategies for regulating river flow helped to flood the riparian mixed forest of the floodplain, it would not have been possible to obtain 25 consecutive days with the

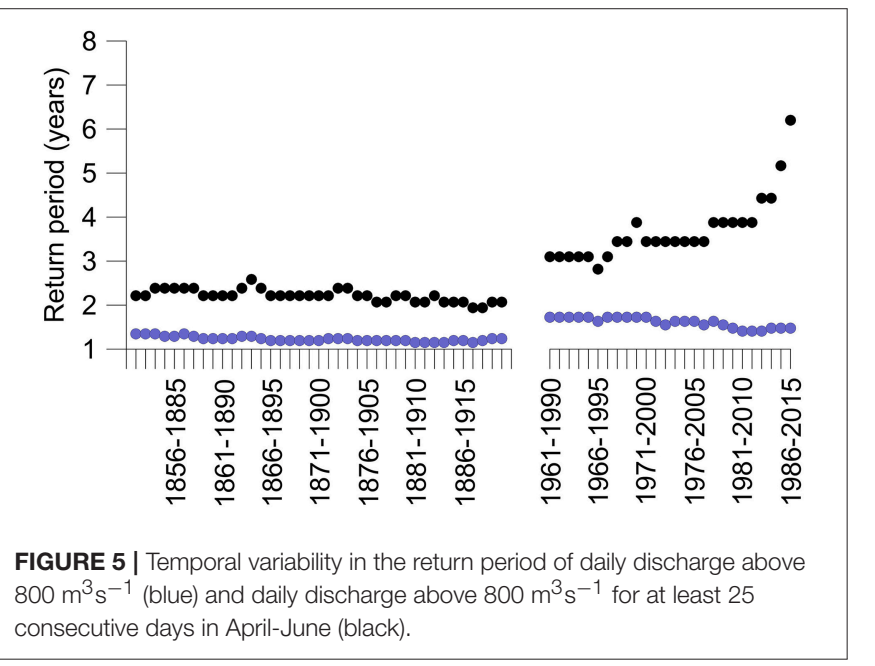

environmental flow of $>800 \mathrm{~m}^{3} \mathrm{~s}^{-1}$ at Näs during the wet years studied using any of the alternative scenarios (Table 1). Even for natural flow, the threshold of 25 days was only achieved during one of the years with extreme high flows (i.e., 2010). The difference in river flow between the two alternatives was not very large; however, the loss in energy production varied considerably (with a loss of some 50-200 GWh, respectively) with alternative No. 2 being much more cost effective (Hedström-Ringvall et al., 2017a). Thus, from only considering these two alternatives and losses in production, only changing the regulation of Lake Siljan came out as the best choice. However, additional challenges with changing this regulation routine include new legal agreements and security design, as well as extremely good monthly river flow forecasts.

\section{DISCUSSION}

This detailed site-specific investigation for adapting the vulnerable riparian mixed forest at the floodplains of Dalälven River to climate change conditions, shows that induced floods by changed hydropower regulation will not help saving $50 \%$ of the habitats. The environmental goals must thus be revised to be realistic under climate change, as the snow storage will most likely be further reduced in the future. Sustainable management of the study site does not request flooding every year, but some every fifth year (Hedström-Ringvall et al., 2017a). The most favorable years could be chosen from snow measurements during winter and seasonal forecasts of the flow peak during spring. Monthly seasonal forecasts of spring flow show skills in the region (Arnal et al., 2017; Foster et al., 2017), although low, and the efficiency of the artificially induced floods will increase with help of natural high flow also from unregulated areas contributing to flooding of the floodplains.

The County Board is currently driving the process locally and will proceed by establishing a working group for the next 5 years to further analyze effects and potential of changed regulations. The environmental flows will be reconsidered regarding area to be flooded, to also investigate the possibilities for sustainable management of smaller areas, which requests lower river flow. Besides from the flooded riparian mixed forest there are also flooded meadows of concern that request lower flow volumes than the forest to become sustainable under climate change.

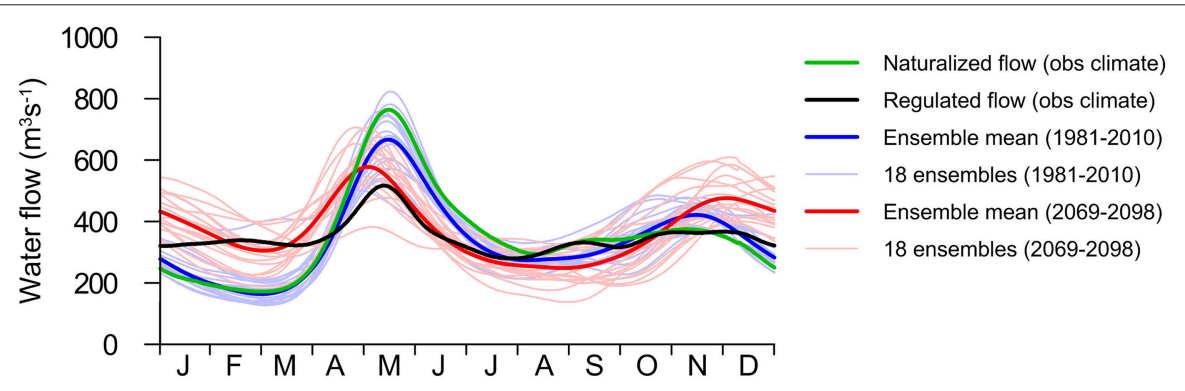

FIGURE 6 | Impact on river flow at Näs by hydropower regulation and climate change, respectively. Regulated flow is observed river flow, while naturalized flow is modeled using the observed climate (green) and the climate model data of current climate (blue) and by the end of the century (red). 
TABLE 1 | Number of days and production losses for different scenarios of artificially induced floods (modified from Hedström-Ringvall et al., 2017a).

\begin{tabular}{|c|c|c|c|c|c|c|c|c|}
\hline \multirow[t]{2}{*}{ Scenario: } & \multicolumn{4}{|c|}{ No. days with river flow $>800 \mathrm{~m}^{3} \mathrm{~s}^{-1}$ at Näs } & \multicolumn{4}{|c|}{ Loss of energy production (GWh) } \\
\hline & 1999 & 2006 & 2010 & 2015 & 1999 & 2006 & 2010 & 2015 \\
\hline B.a.U. ${ }^{1}$ & 0 & 0 & 7 & 4 & NA & NA & NA & NA \\
\hline Alt. No 1 & 14 & 6 & 15 & 12 & 190 & 174 & 200 & 215 \\
\hline Alt. No 2 & 14 & 5 & 11 & 7 & 54 & 47 & 35 & 54 \\
\hline Natural $^{2}$ & 19 & 16 & 26 & 15 & NA & NA & NA & NA \\
\hline
\end{tabular}

NA, Not Applicable.

${ }^{1}$ Business as Usual, using present regulation strategy.

${ }^{2}$ Natural flow, without any regulation.

Both environmental goals will be negotiated and optimized against loss in energy production in new scenarios by the working group, to estimate the most cost effective climate adaptation for floodplains in Dalälven River. In addition, a committee for adaptive management will be established to elaborate operational decision-making of artificial flooding, taking fictive decisions from various sources of support material during spring each of the 5 years.

Finally, it should be mentioned that the hydropower companies and the engineering consultants that have been involved in the calculations for each hydropower dam are more reluctant to changes in regulation strategies. The calculations for each dam were based on statistics and observations, but in reality it would be very difficult to forecast exactly when the flow peaks will reach the riparian mixed forest. There is a high risk that the gates are opened too early or too late, which significantly would affect the result. It is thus difficult to match the flood peak from artificial flooding with the natural flooding from unregulated areas, while the joint effect is needed. The dam operators also see the difficulties in spring-flood forecasting and claim that the methods available are still too poor to be used for decisionmaking. They also see security risks, as when the discharge from Lake Siljan once has started it will be difficult to stop, due to the naturally inherent slowness of the system, and intense rains may challenge the upper limit of the reservoir. The new regulation strategies must thus also be analyzed from a security perspective as the dam was never designed for this purpose and the legal agreements on volume fluctuations must be further validated.

Apart from the concerns about ecology, actual costs and security mentioned here, there are also other policy concerns with changing regulation strategy from hydropower dams. Hydropower is referred to as a clean and renewable energy source, which is favored over fossil fuels. Reservoir storage is often used to balance out fluctuations in other renewable power sources, such as wind and solar, which may become more important in future energy production. Hence, climate mitigation may request more hydropower in the future and more flexible regulation schemes also taking this aspect in concern. Water governance always require collaborations among multiple actors to ensure sustainability in various sectors (Falkenmark and Molden, 2008; Palmer et al., 2009; Grafton et al., 2013). Also other stakeholders representing domestic, industrial, agricultural or recreation interests may have an opinion on regulation strategies, so probably a wider audience must be addressed and consulted during the upcoming 5 years before actual implementation.

\section{CONCLUSIONS}

Our analysis show that annual maximum snow storage in Dalälven River decreases despite an overall slight increase in annual precipitation during the last 55 years, and that these changes can be attributed to climate change. During the same period, hydropower regulations have reduced the flow peaks from snow melting, which naturally should overflow the floodplains. Both changes will affect forest habitats.

Searching for sustainable agroforestry requires an analysis where hydrologists and ecologists work in close collaboration. In lower Dalälven River, riparian biodiversity relies on occasional spring floods with relatively long duration to "reset" habitats. Artificially induced flooding is one possible adaptation measure, although it implies significant costs in lost energy production and changes in both regulation strategies and river basin management plans.

Managing floodplain ecosystems under climate change is facilitated by hydrological modeling tools. In this study we demonstrate that reference conditions are not stationary under climate change, which prevents the use of historic measurements to define reference conditions and targets of river basin management. Rather, reference conditions must be dynamically modeled to be comparable to the present-day situation and for separating the anthropogenic pressures from natural variability.

\section{AUTHOR CONTRIBUTIONS}

BA outlined the manuscript, analyzed the results, and wrote the text. NH collaborated with local stakeholders and made statistical analysis. GL contributed with hydrological modeling, plots, and graphs.

\section{ACKNOWLEDGMENTS}

We would like to thank all participants in the collaborative project Sustainable hydropower in Dalälven River initiated by the Swedish Authority of Marine and Water Management; especially Per-Erik Sandberg (County board of Dalarna), Joel Berglund (County board of Uppsala), Anna Hedström-Ringvall (Regulation company of Daläven River), Claes Kjörk and Kent Pettersson (Fortum), Magnus Engström and Dag Wisaeus (ÅF/Vattenfall). 


\section{REFERENCES}

Andersson, E., Nilsson, C., and Johansson, M. E. (2000). Effects of river fragmentation on plant dispersal and riparian flora. Regulated Rivers Res Manage. 16, 83-89. doi: 10.1002/(SICI)1099-1646(200001/02)16:13.3.CO;2-K

Andréasson, J., Bergström, S., Carlsson, B., Graham, L. P., and Lindström, G. (2004). Hydrological change-climate change impact simulations for Sweden. AMBIO 33, 228-234. doi: 10.1579/0044-7447-33.4.228

Antonson, H., and Jansson, U. (eds) (2011). Agriculture and Forestry in Sweden Since 1900: Geographical and Historical Studies. Stockholm: The Royal Swedish Academy of Agriculture and Forestry.

Arheimer, B., Donnelly, C., and Lindström, G. (2017). Regulation of snow-fed rivers affects flow regimes more than climate change. Nat. Commun. 8:62. doi: $10.1038 /$ s41467-017-00092-8

Arheimer, B., and Lindström, G. (2014). "Electricity vs ecosystems-understanding and predicting hydropower impact on swedish river flow. evolving water resources systems: understanding, predicting and managing water-society interactions," in Proceedings of ICWRS 2014, June 2014 (Bologna: IAHS Publications), 313-319.

Arnal, L., Cloke, H. L., Stephens, E., Wetterhall, F., Prudhomme, C., Neumann, J., et al. (2017). Skilful seasonal forecasts of streamflow over Europe? Hydrol. Earth Syst. Sci. 22, 2057-2072. doi: 10.5194/hess-2017-610

Barnett, T. P., Adam, J. C., and Lettenmaier, D. P. (2005). Potential impacts of a warming climate on water availability in snow-dominated regions. Nature 438:303-309. doi: 10.1038/nature04141

Bergstrand, M., Asp, S., and Lindström, G. (2014). Nationwide hydrological statistics for Sweden with high resolution using the hydrological model SHYPE. Hydrol. Res. 45, 349-356. doi: 10.2166/nh.2013.010

Bunn, S. E., and Arthington A. H. (2002). Basic principles and ecological consequences of altered flow regimes for aquatic biodiversity. Environ. Manage. 30, 492-507. doi: 10.1007/s00267-002-2737-0

Chow, V. T., Maidmeni, D. R., and Ma, L. W. (1988). Applied Hydrology. McGrawHill Series in Water Resources and Environmental Engineering. Berkshire: McGraw-Hill Book Co (UK) Ltd.

Elmhagen, B., Destouni, G., Angerbjörn, A., and Borgström, S., Boyd, E., et al. (2015). Interacting effects of change in climate, human population, land use, and water use on biodiversity and ecosystem services. Ecol. Soc. 20, 1-10. doi: 10.5751/ES-07145-200123

Falkenmark, M., and Molden, D. (2008). Wake up to realities of river basin closure. Water Resour. Dev. 24, 201-215. doi: 10.1080/07900620701723570

Foster, K., Bertacchi Uvo, C., and Olsson, J. (2017). The development and evaluation of a hydrological seasonal forecast system prototype for predicting spring flood volumes in Swedish rivers. Hydrol. Earth Syst. Sci. 22, 2953-2970. doi: 10.5194/hess-2017-588

Godsey, S. E., Kirchner, J. W., and Tague, C. L. (2013). Effects of changes in winter snowpacks on summer low flows: case studies in the Sierra Nevada, California, USA. Hydrol. Process. 28, 5048-5064. doi: 10.1002/hyp.9943

Grafton, R. Q., Pittock, J., Davis, R., Williams, J., Fu, G., Warburton, M., et al. (2013). Global insights into water resources, climate change and governance. Nat. Clim. Change 3, 315-321. doi: 10.1038/nclimate1746

Hedström-Ringvall, A., Kjörk, C., Pettersson, K., Engström, M., Ljung, P., Hjerdt, N., et al. (2017b). Dalälvens Vattenkraftssystem. Report from Länsstyrelsen i Dalarnas län, No. 2017:03, ISSN: 1654-7691, 186 pages (in Swedish).

Hedström-Ringvall, A., Kjörk, C., Pettersson, K., Engström, M., Wisaeus, D., Hjerdt, N., et al. (2017a). Ekologiskt anpassad årsreglering av DalälvenNaturvårdsnytta och påverkan på vattenkraftssystemet, Report from Länsstyrelsen i Dalarnas län, No. 2017:09, ISSN: 1654-7691, 166 pages (in Swedish). Available online at http://www.lansstyrelsen.se/Dalarna/Sv/ publikationer/rapporter-2017/Pages/2017-09.aspx

Johansson, B. (2002). Estimation of Areal Precipitation for Hydrological Modelling in Sweden. PhD Thesis, Earth Sciences Centre, Dept Phys. Geog., Göteborg University, Sweden.

Krasting, J. P., Broccoli, A. J., Dixon, K., and Lanzante, J. (2013). Future changes in northern hemisphere snowfall. J. Clim. 26, 7813-7828. doi: 10.1175/JCLI-D-12-00832.1
KSLA (2015). Forests and Forestry in Sweden. The Royal Swedish Academy of Agriculture and Forestry (KSLA). Available online at: http://www.ksla.se/ wp-content/uploads/2015/08/Forests-and-Forestry-in-Sweden_2015.pdf (in Swedish)

Laudon, H., Sponseller, R. A., Lucas, R. W., Futter, M. N., Egnell, G., et al. (2011). Consequences of more intensive forestry for the sustainable management of forest soils and waters. Forests 2, 243-260. doi: 10.3390/f2010243

Leira, M., and Cantonati, M. (2008). Effects of water-level fluctuations on lakes: an annotated bibliography. Hydrobiologia 613, 171-184. doi: 10.1007/s10750-008-9465-2

Lindström, G., Pers, C., Rosberg, J., Strömqvist, J., and Arheimer, B. (2010). Development and testing of the HYPE (Hydrological Predictions for the Environment) water quality model for different spatial scales. Hydrol. Res. 41, 295-319. doi: 10.2166/nh.2010.007

Lytle, D. A., and Poff, N. L. (2004). Adaptation to natural flow regimes. Trends Ecol. Evol. 19, 94-100. doi: 10.1016/j.tree.2003.10.002

Molini, A., Katul, G. G., and Porporato, A. (2011). Maximum discharge from snowmelt in a changing climate. Geophys. Res. Lett. 38:L05402. doi: 10.1029/2010 GL046477

Nilsson, C., Reidy, C. A., Dynesius, M., and Revenga, C. (2005). Fragmentation and flow regulation of the world's large river systems. Science 308, 405-408. doi: $10.1126 /$ science.1107887

Nilsson, P., Cory, N., and Wikberg, P.-E. (2016). Skogsdata 2016: Aktuella Uppgifter om de Svenska Skogarna från Riksskogstaxeringen, Tema: Skogen då, nu Och $i$ Framtiden. Umeå: Institutionen för skoglig resurshushållning, Sveriges lantbruksuniversitet, SLU. Available online at: http://urn.kb.se/resolve?urn= urn:nbn:se:slu:epsilon-e-3484 (in Swedish)

Palmer, M. A., Lettenmaier, D. P., Poff, N. L., Postel, S. L., Richter, B., and Warner, R. (2009). Climate change and river ecosystems: protection and adaptation options. Environ. Manage. 44, 1053-1068. doi: 10.1007/s00267-0099329-1

Palmer, M. A., Reidy Liermann, C. A., Nilsson, C., Flörke, M., Alcamo, J., Lake, P. S., et al. (2008). Climate change and the world's river basins: anticipating management options. Front. Ecol. Environ. 6, 81-89. doi: 10.1890/060148

Rheinheimer, D. E., and Viers, J. H. (2015). Combined effects of reservoir operations and climate warming on the flow regime of hydropower bypass reaches of California's Sierra Nevada. River Res. Appl. 31, 269-279. doi: 10.1002/rra.2749

Samuelsson, P., Jones, C. G., Willén, U., Ullerstig, A., Gollvik, S., Hansson, U., et al. (2011). The Rossby centre regional climate model RCA3: model description and performance. Tellus A 63, 4-23. doi: 10.1111/j.1600-0870.2010.00478.x

Strömqvist, J., Arheimer, B., Dahné, J., Donnelly, C., and Lindström, G. (2012). Water and nutrient predictions in ungauged basins: set-up and evaluation of a model at the national scale. Hydrol. Sci. J. 57, 229-247. doi: 10.1080/02626667.2011.637497

Yang, W., Andréasson, J., Graham, L. P., Olsson, J., Rosberg, J., and Wetterhall, F. (2010). Distribution based scaling to improve usability of regional climate model projections for hydrological climate change impacts studies. Hydrol. Res. 41, 211-229. doi: 10.2166/nh.2010.004

Zinke, P. (2013). Application of the Building Block Methodology to the Dalälven Project. Länsstyrelsen Gävleborg, Report No. 2013:11. Available online at http:// www.lansstyrelsen.se/Gavleborg/SiteCollectionDocuments/Sv/publikationer/ 2013/RLS_rapporter_Bilagor/Bilaga15_Konekvens_reglering.pdf

Conflict of Interest Statement: The authors declare that the research was conducted in the absence of any commercial or financial relationships that could be construed as a potential conflict of interest.

Copyright (c) 2018 Arheimer, Hjerdt and Lindström. This is an open-access article distributed under the terms of the Creative Commons Attribution License (CC BY). The use, distribution or reproduction in other forums is permitted, provided the original author(s) and the copyright owner(s) are credited and that the original publication in this journal is cited, in accordance with accepted academic practice. No use, distribution or reproduction is permitted which does not comply with these terms. 